\title{
Fire History and Potential Fire Behavior in a Rocky Mountain Foothill Landscape
}

\author{
Yegang Wu + DenNis H. KNIGHT \\ DEPARTMENT OF BOTANY + UNIVERSITY OF WYOMING \\ LARAMIE
}

\begin{abstract}
A landscape approach was used to study fire history and fire behavior in the Douglas-fir forests and foothill vegetation of the Bighorn Canyon National Recreation Area in southcentral Montana. The 3,976 ha study area was divided into 4-ha grid cells, and traditional fire scar analysis and fuel sampling methods were used for data collection in each cell. There have been 15 surface fires during the last 109 years and 10 canopy fires during the last 360 years. The mean fire interval in the forests as a whole, was 7 years for surface fires and 31 years for canopy fires. Using the Weibull function, the recurrent time for fire in a specific grid cell was 212 and 226 years for surface and canopy fires, respectively. The distribution of the probability density function showed that there was a peak of high canopy fire frequency between 150-250 years of stand age. There was no obvious peak period for surface fires in humid ravines, which suggests that surface fires there are not associated with aging. Employing Rothermel's model, a fire behavior model (FIREMDL) was developed and linked it to a geographic information system (GRASS) to simulate
\end{abstract}

flammability of each grid cell under different conditions of fuel moisture and wind velocity. The results suggest that flammability is highly variable because of differences in vegetation and topographic position. The Patterns of flammable and non-flammable grid cells were clearly shown on GIS maps that can be used for locating natural fire breaks and for other fire management purposes. With the development of a process-based landscape model (SPREAD), which was also linked to GRASS, it was possible to predict fire spread from one grid cell to another. SPREAD projects the timing of fire movement and the effect of driving variables (e.g., slope, aspect, fuel amount, fuel moisture, wind speed, and wind direction). The simulations show that fire would not spread in mountain mahogany shrubland and may spread rapidly in juniper woodland under conditions of low fuel moisture and high wind speed $(>425 \mathrm{~m} / \mathrm{min})$. Fire spread in Douglas fir forests is strongly controlled by topography, but wind direction determines the burning pattern in grassland. 